\title{
Ecologists attack endangered-species logjam
}

\section{Betsy Mason, Washington}

US ecologists and environmental groups are becoming increasingly frustrated at what they see as attempts by the Bush administration to hobble the Endangered Species Act.

Since the administration took office in 2001, additions to the endangered species list have plummeted to an average rate of just eight per year, compared with 65 species per year during the Clinton years and 59 per year under George Bush, the current president's father, from 1989 to 1992.

Ecologists also say that actual and pending changes in the law could further curtail the effectiveness of the act, which was passed in 1973 to protect threatened animal and plant species.

"A lot of things that this administration has done have been intended to do harm to the Endangered Species Act," says David Wilcove, an ecologist who studies endangered species at Princeton University, New Jersey.

On 3 December, Defenders of Wildlife, a Washington-based environmental group, issued a report arguing that the administration had failed to request enough funding to support the act and refused to comply with court orders, leaving endangered species such as the manatee and the desert tortoise without protection. "We see a very disturbing picture of an administration attacking the Endangered Species Act," says Rodger Schlickeisen, the group's president.

Craig Manson, the assistant secretary at the US Department of the Interior responsible for implementing the act, says that the report doesn't accurately reflect the administration's treatment of endangered species. He says that efforts to protect species by cooperating with private landowners are paying off."We have put hundreds of millions

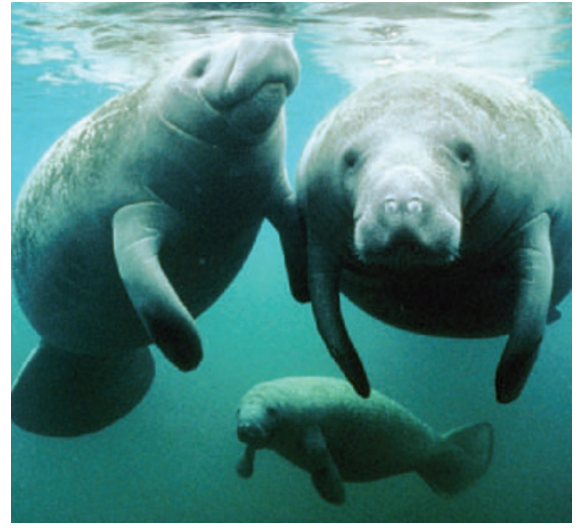

group, agrees that animals such as the northern aplomado falcon in Texas and the nene in Hawaii have benefited from government cooperation with private landowners. "Progress is being made on the ground," he says.

But the news is not all good, says Bean. "There is a concerted effort on the part of the Department of the Interior to diminish provisions of the act," he says.

And, ecologists say, new legislation is set to accelerate the trend. Under the Healthy Forest Restoration Act, for example, which was signed by President Bush on 3 December, federal agencies such as the US Department of Agriculture's Forest Service are no longer required to consult with biologists from the Fish and Wildlife Service before carrying out actions that could affect endangered species.

"This could lead to a situation where harm could be done to endangered species under the radar of the Fish and Wildlife Service," says Wilcove.

An amendment to the Endangered Species Act, introduced in the House of Representatives in April and supported by the Bush administration, would require that only empirical data and peer-reviewed research be considered for species listings and critical habitat designations, rather than the current use of the "best available science".

This would make rare or elusive animals that have received little scientific attention ineligible, says ecologist Gordon Orians, former president of the Ecological Society of America."The idea that you could determine where a population is headed based solely on empirical data without a population model is ridiculous," he says.

"There are a lot of species in big trouble in this country, and they are not all listed yet," says Orians. "It's so discouraging what this administration is trying to do."

\section{Swamp row bogs down Singapore's bid to reclaim land}

\section{David Cyranoski, Singapore}

Marine biologists are being asked to assess the impact of a land-reclamation project off Singapore which, neighbouring Malaysia charges, could damage mangrove swamps and other important ecological features.

In September, Malaysia appealed to the Hamburg-based International Tribunal for the Law of the Sea (ITLOS), asserting that the project infringes on its territory and that Singapore has failed to undertake the environmental assessment required by the United Nations Convention on the Law of the Sea.

And last month, the tribunal ordered the two countries to assemble a group of independent experts to assess the impact of the 33-square-kilometre project, which began three years ago and aims to expand the island of Pulau Tekong, which sits near the mouth of Malaysia's Johor river.

The group is due to report by next October. But in the meantime, some experts are already criticizing the project. Ving Ching Chong, an ecologist at the University of Malaya in Kuala Lumpur, says that it will probably damage mangrove forest at the mouth of the river. He says that the swamps are valuable spawning grounds for marine life, and protect the land behind them from storms.

Chong adds that the project, by constricting the area for water flow, will increase the tidal flow and river current, and wash away the soil in which the trees stand. “They won't be able to take it. They'll just topple over," he says.

But a Singaporean marine biologist, who declined to be named, says that the project is well under way and has had no impact on the mangroves.

Other Singaporean researchers allege that Malaysia's real gripe about the project concerns the access of ships from its ports to shipping routes in the area's crowded seas. 